\title{
IL-10(-1082 G/A) Gene Polymorphism in Iraqi Patients with Scabies
}

\author{
Amerah Abdel Hadi ${ }^{1}$, Alaa Jawad Hassan ${ }^{2}$ \\ ${ }^{1}$ Ph.D. Student, ${ }^{2}$ Prof.Dr., Department of Biology, College of Sciences, University of Babylon, Iraq
}

\begin{abstract}
Scabies is one of a neglected parasitic disease. It causes complications that lead to inflammatory and allergic immune response, Cytokines play an important role in the pathogenesis and disease progression. Various reports have implicated cytokine gene polymorphisms in susceptibility to develop some immune mediated conditions, The purpose of this study was to investigate the association of interleukin -10(IL-10) gene polymorphism with the scabies risk and its effect on IL-10 production . The results revealed that a significant increase $(\mathrm{P} \leq 0.05)$ in levels of IL-10 in patients groups compared with healthy group, also the data found that a statistically higher IL-10 serum levels among carriers of the G allele (G/A heterozygotes or $\mathrm{G} / \mathrm{G}$ homozygotes vs. A/A homozygotes) in the $-1082 \mathrm{G} / \mathrm{A}$ IL-10 polymorphism in both scabietic patients and control groups. The frequencies of genotypes GG and GA of IL-10 (1082 G/A) polymorphism were significantly increased $(\mathrm{P} \leq 0.05)$, whereas genotype AA was decreased in patients than the healthy subjects .IL-10 (1082 G/A) polymorphism was associated with the susceptibility of scabies, thus giving additional support for the genetic basis of this disease
\end{abstract}

Keywords: Scabies, Interleukin-10. Genetic polymorphism

\section{Introduction}

Sarcoptes scabiei var. hominis. is ectoparasitic caused humans scabies ,also is consider ubiquitous disease, with an estimated 300 million infections per annum worldwide ${ }^{1}$. Furthermore, scabies is commonly found within developing countries, low socioeconomic communities and global regions experiencing significant environmental stressors such as during times of war and environmental disasters, ${ }^{2}$.Scabies was transmitted by person to person contact, by infected persons interacting with fomites such as clothing, bedding or shared household items that are contaminated with mites or mite eggs that were shed from infected individuals ${ }^{3}$ meantime, mites can survive without host survive for $24-36 \mathrm{~h}$, at room conditions $\left(21^{\circ} \mathrm{C}\right.$ and $40-80 \%$ relative humidity) ${ }^{4}$. The IL-10 gene maps to the junction of $1 \mathrm{q} 31-\mathrm{q} 32^{5}$ and this gene is highly polymorphic with a number of single nucleotide polymorphisms in the promoter region, in addition there is 3 polymorphic susceptible sites found in IL-10 promoter region include $-1082(\mathrm{G} / \mathrm{A}),-592(\mathrm{C} / \mathrm{A})$ and $-819(\mathrm{C} / \mathrm{T})^{6}$. The aim of this study were to investigate the association between IL-
$10 \mathrm{G}-1082 \mathrm{~A}$ promoter polymorphism of interleukin-10 gene among some Iraqi scabietic patients using ARMSPCR technique .

\section{Materials and Method}

\section{Patients and control:}

A total of 60 patients infected with Sarcoptes scabiei var. hominis (25 males and 35 females) and 30 healthy individuals (15 males and 15 females) were included in current study.

\section{Blood samples :}

The blood samples were drown from each patients and healthy subjects $(5 \mathrm{ml})$. The sample was divided into two parts, the first placed in EDTA tube for genetic study, while the other part was kept to clot at room temperature, then centrifuged at $3000 \mathrm{rpm}$ for 10 minutes, after that sera samples were transferred into eppendrof tubes and stored at deep freeze until used . 


\section{Laboratory investigations :}

\section{A.Immunological assays :}

The levels of IL-10 was estimated by ELISA according to the manual procedure of kits provided by Bioassay Technology Laboratory /UK .

\section{B. PCR amplification}

Genomic DNA was extracted from the blood of scabietic patients and controls using DNA mini kit (favergen-Korea). Interleukin-10 gene was amplified using amplification refractory mutation systems (ARMS)-PCR methodology for IL-10 (1082 GA) according to 77 [. The set of primers used to amplify various types of polymorphism are summarized in table 1 .
The PCR amplification was performed in a total volume of $20 \mu \mathrm{l}$. (master mix is a premixed ready to use solution containing Taq DNA polymerase, dNTPs, $\mathrm{MgCl} 2$ and reaction buffers) supplied by Bioneer company (Korea), $5 \mu \mathrm{L}$ of genomic DNA, $1 \mu \mathrm{l}$ of each primer $(10 \mathrm{pmol} / 1 \mu \mathrm{L})$ and $13 \mu \mathrm{L}$ from nucleases free water for polymorphism IL-10(1082 G/A). Reaction consisted of 10 temperature cycles of denaturation for $15 \mathrm{~s}$ at $94{ }^{\circ} \mathrm{C}$, annealing for 50 $\mathrm{s}$ at $65^{\circ} \mathrm{C}$ and extension for $40 \mathrm{~s}$ at $72{ }^{\circ} \mathrm{C}$. Then 25 cycles of denaturation for $20 \mathrm{~s}$ at $94{ }^{\circ} \mathrm{C}$, annealing for $50 \mathrm{~s}$ at $59^{\circ} \mathrm{C}$, extension for $50 \mathrm{~s}$ at $72^{\circ} \mathrm{C}$. Final extension was performed at $72^{\circ} \mathrm{C}$ for 7 minutes. Electrophoreses of the PCR product was performed in $2 \%$ agarose gel, stained with ethidium bromide and photographed.

Table (1) Primers of IL-10(-1082 G/A)

\begin{tabular}{|l|l|l|}
\hline IL-10(1082 G/A) & Sequences & Product size \\
\hline anti-sense primer & 5'-CAG TGC CAA CTG AGA ATT TGG-3' & \\
\hline Sense primer G & 5'-CTA CTA AGG CTT CTT TGG GAG-3' & 258 bp \\
\hline Sense primer A & 5'-ACT ACT AAG GCT TCT TTG GGA A-3' & \\
\hline
\end{tabular}

\section{Statistical Analysis:}

The results were analyzed by using SPSS version 24.0.The data were expressed by means \pm standard deviation $( \pm \mathrm{SD})$. Multivariable logistic regression was used to determine independent indicators of SNPS and Allels By use OR and CI 95\% . All P values were two-tailed, with a value of less than 0.05 considered statistically significant

\section{Results}

The results in table (2) revealed that a significant differences $(\mathrm{P}<0.05)$ in the levels of IL-10 between patients groups(first infestation and re-infestation) and control group, which reached $251.60 \pm 85.82$ and $177.23 \pm 69.03 \mathrm{pg} / \mathrm{ml}$ in first infestation and re-infestation groups respectively, while it was $42.19 \pm 14.77 \mathrm{pg} / \mathrm{ml}$ in control group .

Table (2): The levels of IL-10( $\mathrm{pg} / \mathrm{ml})$ in patients( first infestation, re- infestation) and control groups .

\begin{tabular}{|l|l|l|l|}
\hline Groups & Mean \pm S.D. & LSD & p.value \\
\cline { 1 - 2 } First Infestation & $251.60 \pm 85.82$ & \multirow{2}{*}{32.926} & \multirow{2}{*}{0.001} \\
\cline { 1 - 2 } Re infestation & $177.23 \pm 69.03$ & & \\
\cline { 1 - 2 } Control & $42.19 \pm 14.77$ & & \\
\hline
\end{tabular}


The distribution of IL-10 (-1082 G/A) variants in patients and controls are summarized in tables 3 and figure1. It can be seen that the frequency of GG and GA genotypes in first infestation, re-infestation and control groups which reached $56.7 \%, 43.3 \%, 35.5 \%$; 40.0\%, $43.3 \%$ and $29.0 \%$ respectively. It was significantly increased in patients than control, in which GG genotype increased as rate $\mathrm{OR}=3.834$ compared with GA and AA genotypes in studied groups. On the other hand, the frequency of AA genotype in first infestation, re-infestation and control groups was 3.3\%,13.3\% and $35.5 \%$ respectively, that decreased in patients compared with control group .The distribution of IL10 (-1082 G/A) genotypes in first infestation group was AA (homozygous mutant type), GA (heterozygous) in frequencies rate $3.3 \%$ and $40.0 \%$ respectively, but without significance or odd ratio, also the distribution of IL-10 (-1082 G/A) genotypes in re- infestation group were AA,
GA in frequencies rate $13.3 \%$ and $43.3 \%$ respectively, without significance but $\mathrm{OR}=1.222$, as consider $\mathrm{GG}$ reference category .Moreover, the distribution of IL-10 $(-1082 \mathrm{G} / \mathrm{A})$ allele in first infestation, re- infestation and control groups were in A allele frequency rate $23.3 \%$, $35.0 \%$ and $50.0 \%$ respectively, but significantly without OR, while between first infestation and control groups was significant but without $\mathrm{OR}$, in addition between re- infestation and control was non- significant and OR ,in the other hand the distribution of IL-10 (-1082 G/A) allele in first infestation, re- infestation and control groups were $\mathrm{G}$ allele frequency rates $76.7 \%, 65.0 \%$ and $50.0 \%$ respectively, but significantly with $\mathrm{OR}=1.815$ can consider a risk factor with scabies, while between first infestation and control group was significant with $\mathrm{OR}=3.286$, whereas between re- infestation and control group was non- significant and with $\mathrm{OR}=1.857$.

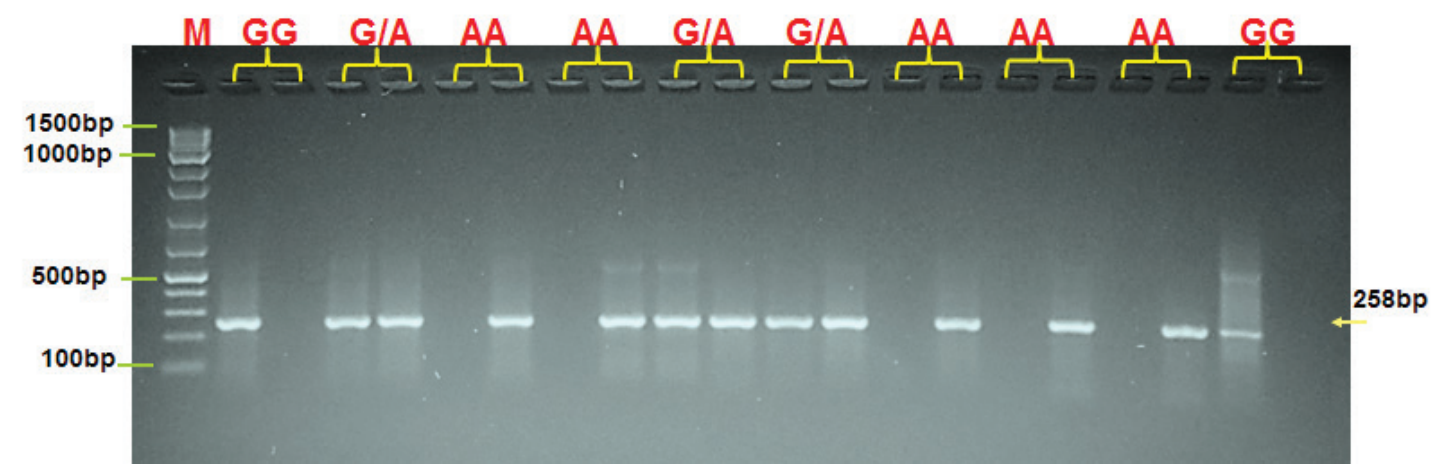

Figure 1: Agarose gel electrophoresis image that showed the two reaction ARMS-PCR product analysis of IL-10 (1082) (G/A) gene polymorphism. Where M: marker (1500-100bp). The GG wild type homozygote genotype lanes were showed only $G$ allele amplification at 258bp ARMS PCR product size. The AA mutant type homozygote genotype lanes were showed only A allele amplification at $258 \mathrm{bp}$ ARMS PCR product size. In addition, the G/A heterozygote genotype lanes were showed G allele and A allele amplification at $258 \mathrm{bp}$ and $258 \mathrm{bp}$ product size respectively

Table(3): Genotype and allele frequencies of IL-10 (-1082) variants in scabietic patients with and control groups.

\begin{tabular}{|c|c|c|c|c|c|c|c|c|}
\hline \multirow{2}{*}{ IL-10 SNPS } & \multicolumn{2}{|l|}{ Study groups } & \multirow[b]{2}{*}{ Control } & \multirow{2}{*}{ Total } & \multirow{2}{*}{ P.value. } & \multirow{2}{*}{ OR } & \multicolumn{2}{|c|}{ 95\% C.I.for OR } \\
\hline & First infestation & $\begin{array}{l}\text { Re- } \\
\text { infestation }\end{array}$ & & & & & Lower & Upper \\
\hline \multirow{4}{*}{$\mathbf{A A}$} & 1 & 4 & 11 & 16 & 0.100 & 0.648 & 0.387 & 1.086 \\
\hline & \multirow{3}{*}{$3.3 \%$} & \multirow{3}{*}{$13.3 \%$} & \multirow{3}{*}{$35.5 \%$} & \multirow{3}{*}{$17.6 \%$} & 0.011 & 0.059 & 0.007 & 0.522 \\
\hline & & & & & 0.098 & 0.308 & 0.076 & 1.245 \\
\hline & & & & & 0.160 & 0.191 & 0.019 & 1.921 \\
\hline
\end{tabular}


Cont... Table(3): Genotype and allele frequencies of IL-10 (-1082) variants in scabietic patients with and control groups.

\begin{tabular}{|c|c|c|c|c|c|c|c|c|}
\hline \multirow{4}{*}{ GA } & 12 & 13 & 9 & 34 & 0.373 & 0.789 & 0.468 & 1.330 \\
\hline & \multirow{3}{*}{$40.0 \%$} & \multirow{3}{*}{$43.3 \%$} & \multirow{3}{*}{$29.0 \%$} & \multirow{3}{*}{$37.4 \%$} & 0.801 & 0.863 & 0.273 & 2.724 \\
\hline & & & & & 0.737 & 1.222 & 0.380 & 3.935 \\
\hline & & & & & 0.522 & 0.706 & 0.243 & 2.050 \\
\hline \multirow{4}{*}{ GG } & 17 & 13 & 11 & 41 & 0.003 & $3.834^{*}$ & 1.593 & 9.229 \\
\hline & \multirow{3}{*}{$56.7 \%$} & \multirow{3}{*}{$43.3 \%$} & \multirow{3}{*}{$35.5 \%$} & \multirow{3}{*}{$45.1 \%$} & 0.261 & 1.545 & 0.724 & 3.299 \\
\hline & & & & & 0.683 & 1.182 & 0.529 & 2.638 \\
\hline & & & & & 0.467 & 1.308 & 0.635 & 2.692 \\
\hline \multirow{2}{*}{ Total } & 30 & 30 & 31 & 91 & & & & \\
\hline & $100.0 \%$ & $100.0 \%$ & $100.0 \%$ & $100.0 \%$ & & & & \\
\hline \multirow{4}{*}{ A } & 14 & 21 & 31 & 66 & 0.003 & 0.551 & 0.374 & 0.811 \\
\hline & \multirow{3}{*}{$23.3 \%$} & \multirow{3}{*}{$35.0 \%$} & \multirow{3}{*}{$50.0 \%$} & \multirow{3}{*}{$36.3 \%$} & 0.003 & 0.304 & 0.140 & 0.663 \\
\hline & & & & & 0.095 & 0.538 & 0.260 & 1.115 \\
\hline & & & & & 0.240 & 0.667 & 0.339 & 1.311 \\
\hline \multirow{4}{*}{ G } & 46 & 39 & 31 & 116 & 0.003 & $1.815^{*}$ & 1.232 & 2.675 \\
\hline & \multirow{3}{*}{$76.7 \%$} & \multirow{3}{*}{$65.0 \%$} & \multirow{3}{*}{$50.0 \%$} & \multirow{3}{*}{$63.7 \%$} & 0.003 & 3.286 & 1.509 & 7.155 \\
\hline & & & & & 0.095 & 1.857 & 0.897 & 3.844 \\
\hline & & & & & 0.448 & 1.179 & 0.770 & 1.807 \\
\hline \multirow{2}{*}{ Total } & 60 & 60 & 62 & 182 & & & & \\
\hline & $100.0 \%$ & $100.0 \%$ & $100.0 \%$ & $100.0 \%$ & & & & \\
\hline
\end{tabular}

*first infestation/control

*re-infestation/control

*first infestation/re-infestation

The correlation between genotype of IL-10 (1082 G/A) and level of IL-10 in patients and control groups was appeared in table (4). The results found that a statistically higher serum levels of IL-10 in patients that carry of
$\mathrm{G}$ allele (G/A heterozygotes or $\mathrm{G} / \mathrm{G}$ homozygotes), in which the IL-10 levels in first infestation, re-infestation and control groups were $290.96,229.22$ and $56.93 \mathrm{pg} / \mathrm{ml}$ respectively for GG genotype , whereas it was 210.62 , 154.09 and $43.43 \mathrm{pg} / \mathrm{ml}$ respectively for GA genotype.

On the other hand, there was lower in level of IL-10 serum in patients that carry of A allele(AA homozygote 
mutant type), in which its levels in first infestation, re-infestation and control groups was $74.11,83.44$ and 27.98 pg/ $\mathrm{ml}$ respectively for AA genotype .

Table (4): The correlation between IL-10 (1082 G/A) genotype and IL-10 (pg/ml) level in patients and control groups.

\begin{tabular}{|l|l|l|l|l|l|l|l|}
\hline \multirow{2}{*}{$\begin{array}{l}\text { IL-10 } \\
\text { SNPS }\end{array}$} & \multicolumn{2}{|l|}{ First infestation } & \multicolumn{2}{l|}{ Re-infestation } & \multicolumn{2}{l|}{ Control } & \multirow{2}{*}{$\begin{array}{l}\text { Sig. } \\
\text { multivariant }\end{array}$} \\
\cline { 2 - 8 } & N & Mean \pm SD & N & Mean \pm SD & N & Mean \pm SD & \multirow{2}{*}{$<0.001$} \\
\hline AA & 1 & $74.11 \pm 7.25$ & 4 & $83.44 \pm 29.80$ & 11 & $27.98 \pm 6.41$ & \\
\hline GA & 12 & $210.62 \pm 57.73$ & 13 & $154.09 \pm 52.34$ & 9 & $43.43 \pm 7.84$ & \\
\hline GG & 17 & $290.96 \pm 78.64$ & 13 & $229.22 \pm 45.97$ & 11 & $56.93 \pm 10.44$ & \\
\hline Total & 30 & $251.60 \pm 85.82$ & 30 & $177.23 \pm 69.03$ & 31 & $42.74 \pm 14.84$ & \\
\hline SIG. & 0.002 & & $<0.001$ & & $<0.001$ & & \\
\hline
\end{tabular}

\section{Discussion}

There are a significant differences in the levels of IL10 between the three groups of the study. 8 [Illustrated that there was a significant differences in the levels of IL-10 between patients and healthy groups which reached $269 \pm 112 \mathrm{pg} / \mathrm{ml}$, also the anti-inflammatory $\mathrm{Th} 2$ cytokines such as IL-10 and not the humoral immunity may play a protective role to guard against severe manifestations in human scabies .According to the current study, IL-10 may be regarded a natural regulator of mast cells activator that reduces inflammation and irritability related to allergic reactions. 19 [showed that the significant increase in levels of IL-10 when used extract mite CO8-stimulated PBMC from control subjects, were it consistent with previous studies that used whole SM extract remarked that the significantly increased levels of IL-10]10 [ .

Finally ]10 [mentioned that the scabies mites are the source of substances that may delay the hosts primary immune response by stimulating the proliferation of regulatory $\mathrm{T}$ cells by their secretion of IL-10 and TGF- $\beta$ which leads to inhibits an inflammatory/immune reaction to the parasite.

Studies revealed that those individuals may have a genetic predisposition that increasing susceptibility to ordinary scabies (OS), therefore, these genetic changes may not directly cause OS, but may play an important role in its development.

The results of present study found that a statistically higher IL-10 serum levels among carriers of the G allele (G/A heterozygotes or $\mathrm{G} / \mathrm{G}$ homozygotes vs. A/A homozygotes) in the $-1082 \mathrm{G} / \mathrm{A}$ IL-10 polymorphism in both scabietic patients and control groups.

The frequencies of genotypes GG and GA of IL-10 (1082 G/A) polymorphism were significantly increased, whereas genotype AA was decreased in scabietic patients than the healthy subjects.

There was no previous studies related with IL10 (1082 G/A) polymorphism in scabietic patients, therefore, the data of current study of polymorphism of IL-10 (1082 G/A) was compared with the psoriasis and atopic dermatitis patients as dermatologic diseases. ]11 [and ]12 [ reported that the regulation of IL-10 gene, there exists a requirement of consideration of knowing genetic variation among patients or healthy subjects groups, in which the genetic variation can possibly effect the expression of the gene and can considerably act as a genetic marker in disease susceptibility or disease severity. The $1082 \mathrm{G}$ allele of IL-10(-1082G/ A) is reported to be associated with high IL-10 gene 
expression, as shown in study.

The frequencies of genotypes GG and AA of IL-10 (1082 G/A) polymorphism were significantly increased, whereas genotype GA was decreased in $\mathrm{AD}$ patients than the controls, in which the IL-10 (-1082 G/A) polymorphisms are linked with the susceptibility of $\mathrm{AD}$ in Saudis and can be regarded a risk factor of IL10 ]13 [. ]14 [ studied the IL-10 serum level and IL10 (1082 G/A) polymorphism in patients with AD and suggested that a role of $\mathrm{G}$ allele in synthesis of IL-10 in the patients with moderate to severe AD. However, IL-10 being immunosuppressive cytokine inhibits the activity of Th1 and Th2 cell types in human subjects. ]15 [ reported that genotype IL-10 (-1082 AG) is susceptible, whereas IL-10 (-1082 AA) is protective to AD in population of Macedonians, while IL-10-1082 G allele has been considered to be associated with higher production of IL-10 from peripheral mononuclear cells ]16,17,18 [, also ]19 [ revealed that carriers of the IL$10-1082 \mathrm{G}$ allele had higher mucosal IL-10 mRNA than -1082A allele carriers. The current study shows IL-10 having both immunosuppressive in first infestation and protective in re-infestation groups, also GG and GA genotypes with high production of IL-10 belong to gene expression people with $G$ allele transcription factors association tight with mRNA, while to gene expression people with A allele transcription factors association weak with mRNA.

Financial Disclosure: There is no financial disclosure.

Conflict of Interest: None to declare.

Ethical Clearance: All experimental protocols were approved under the College of Sciences and all experiments were carried out in accordance with approved guidelines.

\section{References}

1. Haidan A, Talay S, Rohde M, Sriprakash K, Currie $\mathrm{B}$, Chhatwal G. Pharyngeal carriage of group $\mathrm{C}$ and group $\mathrm{G}$ streptococci and acute rheumatic fever in an Aboriginal population. Lancet. 2000; 356(9236): 1167-1169.

2. Wong L, Amega B, Connors C, Barker R, Dulla M, Ninnal A. Kolumboort L. Cumaiyi M M. and Currie B J. Outcome of an interventional program for scabies in an Indigenous community. Med J Aust. 2001; 175(7): 367-370.

3. Mellanby K. The development of symptoms, parasitic infection and immunity in human scabies. Parasitology. 1944; 35(04): 197-206.

4. Meinking $\mathrm{T}$ L, Burkhart CG, Burkhart C N. Ectoparasitic diseases in dermatology: reassessment of scabies and pediculosis. In: James W (ed.). Advances in Dermatology. 1999;15:67-108.

5. Young H, Sang-Cheol B, Sung J, Jong D, Gwan G. Associations between interleukin-10 polymorphisms and susceptibility to rheumatoid arthritis: a meta-analysis. Mol. Biol. Rep. 2012; 39: 81-87.

6. Smith A. and Humphries S. Cytokine and cytokine receptor gene polymorphisms and their functionality. Cytokine \& Growth Factor Reviews. 2009; 20:43-59.

7. Perrey C, Turner S J, Pravica V, Howell W, Hutchinson I V. ARMS-PCR methodologies to determine IL-10, TNF-alpha, TNF-beta and TGFbeta 1 gene polymorphisms. Transpl Immunol. 1999;7:127-8.

8. Abd EL-Aal A, Hassan M, Gawdat H, Ali M, Barakat M. Immunomodulatory impression of anti and pro-inflammatory cytokines in relation to humoral immunity in human scabies Int. J..Immunopath. Pharma. 2016; 29(2) :188-194.

9. Walton S F. The immunology of susceptibility and resistance to scabies. Parasite Immunol. 2010;32:532-40.

10. Arlian L G. Morgan M S. and Paul C C. Evidence that scabies mites (Acari: Sarcoptidae) influence production of interleukin-10 and the function of Tregulatory cells ( $\operatorname{Tr} 1)$ in humans. J Med Entomol. 2006; 43(2):283-7.

11. Eskdale J, Gallagher G, Verweij C L. Keijsers V. Westendorp R G. and Huizinga T W. Interleukin 10 secretion in relation to human IL-10 locus haplotypes. Proc Natl Acad Sci. 1998;95:9465-70.

12. Reuss E, Fimmers R, Kruger A. Becker C. Rittner $\mathrm{C}$ and Höhler $\mathrm{T}$. Differential regulation of interleukin-10 production by genetic and environmental factors-a twin study. Genes Immun. 2002;3:407-13.

13. Huraib G B, Al Harthi F, Arfin M. Al-Sugheyr M. Rizvi S. and Al-Asmari A. Cytokine Gene Polymorphisms in Saudi Patients With Atopic 
Dermatitis: A Case-Control Study, Biomarker Insights. 2018;13: 1-7.

14. Lesiak A, Zakrzewski M, Przybyłowska K, Rogowski-Tylman M. Wozniacka A. and Narbutt J. Atopic dermatitis patients carrying $G$ allele in -1082 G/A IL-10 polymorphism are predisposed to higher serum concentration of IL-10. Arch Med Sci. 2014;10:1239-1243.

15. Reich K, Westphal G, König I R. Mössner R. Schupp P. Gutgesell C. Hallier E. Ziegler A. and Neumann C. Cytokine gene polymorphisms in atopic dermatitis. Br J Dermatol . 2003;148: 1237 1241.

16. Cavet J, Middleton $\mathrm{P}$, Segall $\mathrm{M}$, Noreen $\mathrm{H}$. Davies S M. and Dickinson A M. Recipient tumor necrosis factor-alpha and interleukin-10 gene polymorphisms associate with early mortality and acute graft versus host disease severity in HLAmatched sibling bone marrow transplants. Blood. 1999;94:3941-6.

17. .Koss K, Satsangi J, Fanning G C. Welsh K I. and Jewell D P. Cytokine (TNF alpha, LT alpha and IL-10) polymorphisms in inflammatory bowel diseases and normal controls: differential effects on production and allele frequencies. Genes Immun. 2000;1:185-90.

18. Shahab R, Loo D S. Bullous scabies. J Am Acad Dermatol. 2003;49 (2): 346-350.

19. Rad R, Dossumbekova A, Neu B. Lang R. Bauer S. Gerhard S M.and et al. Cytokine gene polymorphisms influence mucosal cytokine expression, gastric inflammation, and host specific colonization during Helicobacter pylori infection. Gut. 2004;53:1082-9. 